Article

\title{
Palladium-catalyzed synthesis of indole-3-alkynones via direct carbonylation of indoles
}

\author{
LI Dengfeng a,b, SHAN Shang b, SHI Lijuna, LANG Rui a, XIA Chungu a, LI Fuwei a,* \\ a State Key Laboratory for Oxo Synthesis and Selective Oxidation, Lanzhou Institute of Chemical Physics, Chinese Academy of Sciences, Lanzhou 730000, \\ Gansu, China \\ ${ }^{\mathrm{b}}$ College of Chemical Engineering and Materials Science, Zhejiang University of Technology, Hangzhou 310014, Zhejiang, China
}

\section{A R T I C L E I N F O}

\section{Article history:}

Received 6 November 2012

Accepted 20 November 2012

Published 20 January 2013

\section{Keywords:}

Carbonylation

Carbon monoxide

Palladium

Indole-3-alkynone

Triazole

\begin{abstract}
A B S T R A C T
A new method has been developed for the Pd-catalyzed direct carbonylation of indoles with phenylacetylenes. The process involved the initial iodination of the indole to afford the corresponding 3 -iodo-indole, which was subsequently carbonylated with a variety of different alkynes using $\operatorname{Pd}(0)$ to yield the indole-3-alkynones. In contrast to the traditional Pd-catalyzed oxidative carbonylation strategy, which involves the Pd(II)-mediated activation of the aromatic C-H bonds, the aromatic C$\mathrm{H}$ bonds in the current process were activated by iodine oxidation, eliminating the problems associated with the reduction of $\mathrm{Pd}(\mathrm{II})$ to $\mathrm{Pd}(0)$ under the $\mathrm{CO}$ atmosphere. Following an extensive screening process, $\mathrm{Pd}(\mathrm{OAc})_{2} / \mathrm{CuI}$ was identified as the most efficient catalyst system for the reaction in the presence of a base and iodine as an oxidant under mild conditions $\left(0.2 \mathrm{MPa} \mathrm{CO}, 90^{\circ} \mathrm{C}\right)$. The reaction provided the desired products in moderate to excellent isolated yields (up to 94\%) and good tolerance to a variety of different functional groups. The structure of a representative alkynone product (3he) was unambiguously verified by X-ray single crystal structure analysis. Furthermore, the carbonylation products underwent a three-component reaction with sodium azide and benzyl bromide to give the corresponding 1,2,3-triazole analogues in the absence of any catalyst, thus expanding the synthetic application of the current methodology.
\end{abstract}

(C) 2013, Dalian Institute of Chemical Physics, Chinese Academy of Sciences. Published by Elsevier B.V. All rights reserved.

\section{Introduction}

(Hetero)aryl alkynones are powerful building blocks in organic synthesis where they have been used in the preparation of a wide range of natural products and bioactive heterocycles [1]. Aryl alkynone derivatives have traditionally been synthesized via the Sonogashira coupling of aryl acid chlorides with alkynes (Scheme 1, Path 1) [2]. Unfortunately, however, the aryl acid chlorides required for this approach can be unstable and poorly tolerated under the reaction conditions (e.g., indole-3-acid chloride), leading to limitations in the scope of this transformation. Another facile protocol for the synthesis of alkynone derivatives involves the transition-metal catalyzed Sonogashira carbonylation reaction between an aryl halide and an alkyne in the presence of carbon monoxide [3-6]. The advantage of this particular approach is that the starting materials are relatively simple, with aryl iodides and bromides being used in most cases. In 2011, Wu et al. [7] reported the carbonylative Sonogashira coupling of aniline and phenylacetylene to generate the corresponding alkynone via the in-situ generated arenediazonium salt, which effectively accelerated the reaction. Over the past few decades, transition-metal catalyzed carbonylation reactions involving the functionalization of aryl $\mathrm{C}-\mathrm{H}$ bonds have been explored extensively, resulting in the

\footnotetext{
* Corresponding author. Tel: +86-931-4968528; Fax: +86-931-4968129; E-mail: fuweili@licp.cas.cn This work was supported by National Natural Science Foundation of China (21002106 and 21133011). DOI: 10.1016/S1872-2067(11)60491-9
} 


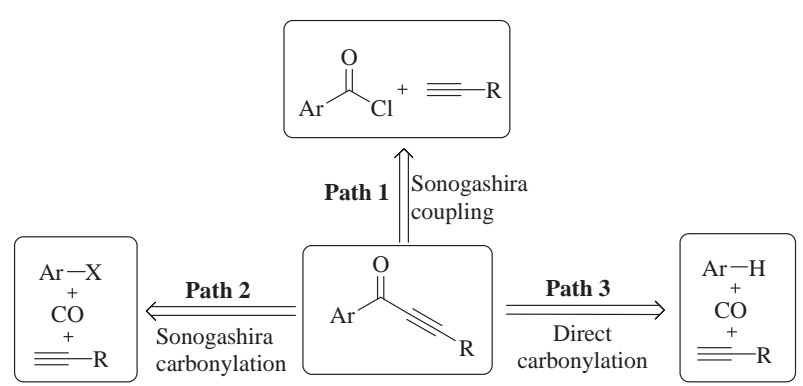

Scheme 1. Strategy available for the synthesis of ynones.

successful syntheses of a variety of different aryl acids, esters, and amides [8-10]. To date, however, the direct synthesis of aryl alkynones from unactivated arenes has never been reported.

Substituted indoles are the key structural components of a number of biologically active synthetic compounds and natural products. For this reason, the functionalization of indole derivatives has attracted considerable levels of attention. Based on our previous efforts towards the development of novel transition-metal mediated synthetic methods [11-19], we have successfully developed a series of reactions for the direct carbonylation of heterocycles [20-24]. Herein, we report the $\mathrm{Pd} / \mathrm{CuI}$-catalyzed direct Sonogashira carbonylation coupling reaction of indoles and alkynes in the presence of iodine as an oxidant.

\section{Experimental}

\subsection{General experimental}

All of the reagents and free (NH)-indole compounds were purchased and used as received without further purification. In contrast, the $N$-substituted indoles were synthesized according to procedures from the literature [25-27]. The NMR spectra of the products were recorded using a Bruker Avance TM spectrometer operating at $400 \mathrm{MHz}$ for the ${ }^{1} \mathrm{H}$ NMR spectra and 100 $\mathrm{MHz}$ for ${ }^{13} \mathrm{C}$ NMR spectra. $\mathrm{CDCl}_{3}$ was used as an NMR solvent unless otherwise stated. The compounds were also analyzed by high resolution mass spectroscopy (HRMS) on a Bruker Daltonics micro TOF-spectrometer. High-performance liquid chromatography (HPLC) analysis was performed on an Agilent 1260 Infinity with an Agilent ZORBAX $C_{18}$ column $(150 \times 4.6$ $\mathrm{mm}$ ) using diphenylacetylene as an internal standard. X-ray single crystal diffraction measurements were conducted at 296 K on a Bruker APEX II diffractometer using Mo $K_{\alpha}$ radiation $(\lambda=$ $0.71073 \mathrm{~nm}$ ). The data were corrected for Lorentz and polarization effects with the SMART software suite and for absorption effects with the SADABS program. The structure was solved by direct methods using the SHELXS program. Isolated yields refer to the amounts obtained by column chromatography on silica gel (200-300 mesh), using a mixture of ethyl acetate and petroleum ether as the eluent.

\subsection{General procedure for Pd-catalyzed carbonylation of indoles with alkynes}

Indole $(0.5 \mathrm{mmol})$, phenylacetylene $(1.0 \mathrm{mmol}), \mathrm{I}_{2}(1.2$ mmol), $\mathrm{K}_{2} \mathrm{CO}_{3}$ (1.5 mmol), CuI (3 mol\%), $\mathrm{Pd}(\mathrm{OAc})_{2}$ (5 mol\%), and DMF (3.0 ml) were added sequentially to a $100 \mathrm{ml}$ stainless steel autoclave. The autoclave was then closed and purged three times with $\mathrm{CO}$ before being pressurized with $0.2 \mathrm{MPa}$ of CO gas. The reactor was then immersed in an oil bath preheated at $90{ }^{\circ} \mathrm{C}$ for $24 \mathrm{~h}$. The mixture was then cooled to ambient temperature and the excess $\mathrm{CO}$ discharged from the system. The reaction mixture was then purified by flash chromatography using silica gel to afford the desired product.

\section{Results and discussion}

\subsection{Optimization conditions}

The direct carbonylation of $N$-methylindole (1a, $0.5 \mathrm{mmol}$ ) with phenylacetylene $(2 \mathrm{a}, 1.0 \mathrm{mmol})$ was used as a model reaction for the optimization of the reaction conditions, as shown in Table 1 . The reaction was conducted in the presence of the classical carbonylation catalyst derived from $\mathrm{Pd}(\mathrm{OAc})_{2}$ and the bidentate 1,1'-bis(diphenylphosphino)ferrocene (dppf) ligand together with $\mathrm{I}_{2}$ (oxidant) and $\mathrm{K}_{2} \mathrm{CO}_{3}$ (base). Pleasingly, the desired indole-3-alkynone product (3aa) was obtained when the reaction was conducted with heating at $110{ }^{\circ} \mathrm{C}$ for $24 \mathrm{~h}$ (Table 1, entry 1). Surprisingly, the use of $\mathrm{Pd}(\mathrm{OAc})_{2}$ alone provided a higher level of catalytic activity (73\% yield) under the same reaction conditions (Table 1, entry 2). Given that $\mathrm{CuI}$ is well known to react with alkynes to generate the corresponding copper acetylide intermediates in situ, it was assumed for the current work that the addition of CuI could promote the reaction. In practice, the yield of 3aa was increased to $82 \%$ (Table 1, entry 3) following the introduction of a catalytic amount of $\mathrm{CuI}$ (3 mol\%). Pleasingly, further experimentation revealed that the reaction provided a higher yield of the prod-

Table 1

Screening of reaction conditions.

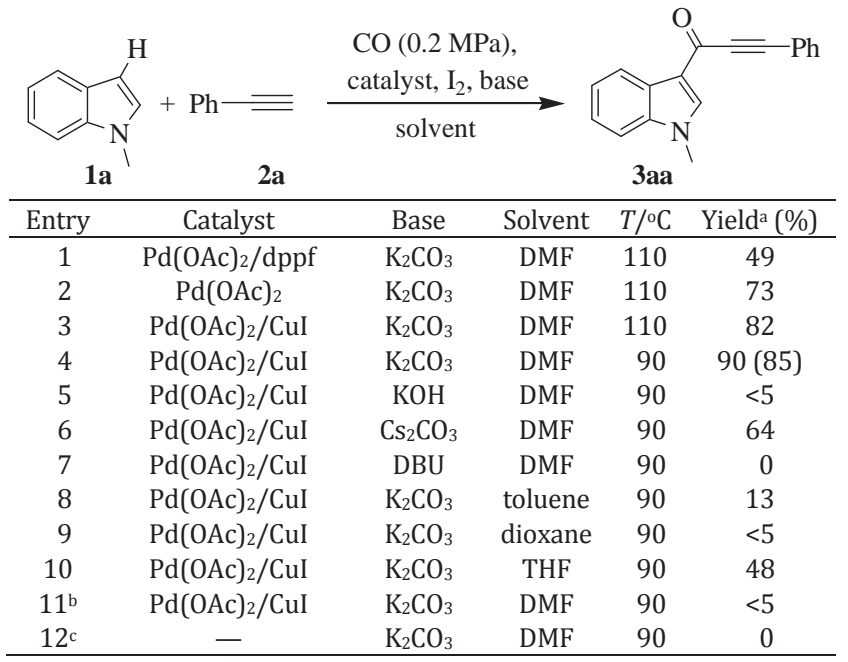

Reaction conditions: 1a $(0.5 \mathrm{mmol}), \mathbf{2 a}(1.0 \mathrm{mmol}), \mathrm{I}_{2}(1.2 \mathrm{mmol})$, base (1.5 mmol), CuI (3 mol \%) and catalyst (5 mol \%) in solvent $(3.0 \mathrm{ml})$ under CO (0.2 MPa) for $24 \mathrm{~h}$. a Determined by HPLC analysis and based on 1a, isolated yield in parentheses. ${ }^{b}$ Base $(1.0 \mathrm{mmol}) .{ }^{\mathrm{c}}$ Without $\mathrm{Pd}(\mathrm{OAc})_{2}$ or $\mathrm{I}_{2}$. 
uct when it was conducted at a lower temperature (Table 1, entry 4). This increase in the yield was attributed predominantly to a reduction in the rate of a competing side reaction involving the coupling of the phenylacetylenes. Different bases were also investigated and $\mathrm{K}_{2} \mathrm{CO}_{3}$ was found to be the most effective base for the current transformation. Some stronger inorganic bases such as $\mathrm{KOH}$ and $\mathrm{Cs}_{2} \mathrm{CO}_{3}$ and the organic base 1,8-diazabicycloundec-7-ene (DBU) all failed to provide satisfactory results (Table 1, entries 5-7). Of the solvents screened for the transformation, $N, N$-dimethylformamide (DMF) provided the best results. The use of tetrahydrofuran (THF) led only to a moderate yield of the product, whereas only a trace of the target product was detected when the reaction was conducted in dioxane (Table 1, entries 8-10). Further experimentation concerning the base revealed that a reduced charge of the base $(1.0 \mathrm{mmol})$ had a severe adverse impact on the reaction yield (Table 1, entry 11). Control experiments to evaluate the roles of the Pd catalyst and the iodine oxidant revealed that both reagents were critical to the success of the transformation (Table 1, entry 12). Taken together, these results indicated that the optimized reaction conditions required the reaction of $\mathbf{1 a}$ (0.5 mmol), 2a (1.0 mmol), Pd(OAc)2 (5 mol\%), CuI (3 mol\%), $\mathrm{K}_{2} \mathrm{CO}_{3}(1.5 \mathrm{mmol})$, and $\mathrm{I}_{2}(1.2 \mathrm{mmol})$ in DMF under $0.2 \mathrm{MPa}$ of $\mathrm{CO}$ at $90^{\circ} \mathrm{C}$ for $24 \mathrm{~h}$.

\subsection{Substrate scope of indole derivatives}

With the optimized conditions in hand, we proceeded to explore the substrate scope of the carbonylation reaction using a variety of different indoles with phenylacetylene as shown in Scheme 2. The carbonylation of indoles bearing a variety of different $\mathrm{N}$-protecting groups proceeded smoothly, to give the desired indole-3-alkynones (3aa-3ea) in moderate to good yields. Unfortunately, however, none of the desired product (3fa) was observed when the indole was $N$-substituted with a strong electron-withdrawing group such as a Tosyl (Ts) group, suggesting that the presence of the Ts group rendered the indole ring highly electron-deficient and retarded the rate of the desired reaction.

The influence of different substituent groups on the benzene ring of $N$-methylindole was then examined (3ga-3qa). Indoles bearing methyl groups underwent the reaction with moderate yields (65\%-85\%), with 5- and 7-methyl- $N$-methylindole (3ha and $3 \mathbf{j a}$ ) showing higher levels of reactivity than the 4- and 6-substituted $N$-methylindoles (3ga and 3ia). Similarly, when a methoxy group was present at the 5-position of the indole (3ga), a slight improvement in the yield was obtained relative to the corresponding indole bearing a methoxy group at the 6-position (3la). In general, indoles bearing electron-withdrawing groups on the benzene ring such as an ester, bromide, chloride, and fluoride (3ma-3qa) showed better levels of reactivity than those bearing electron-donating groups (3ga-3la), regardless of the position of the substituent. It is noteworthy that indoles bearing halide substituents (3na-3qa) were well tolerated under the optimized reaction conditions, and could therefore provide a useful handle for the further functionalization of the products. The reactivities of a variety of different substituted $N$-allylindoles were also tested (3ra-3va), with reasonable yields being obtained in all cases. When $\mathrm{N}$-benzylindoles bearing an electron-donating group were employed as the substrate, yields in excess of $90 \%$ were achieved (3wa and 3xa). In contrast, the use of an $N$-benzylindole bearing a bromide at the 5-position gave no reaction at all (3ya).

\subsection{Substrate scope of alkynes}

In addition to evaluating the substrate scope of the transformation with a range of substituted indoles, the effects of different substituents on the phenylacetylene derivatives were also investigated, as shown in Scheme 3. $\mathrm{N}$-Methylindole reacted smoothly with a variety of different $p$-substituted phenylacetylenes under the optimized reaction conditions to give<smiles>[R]c1ccc2c(c1)c(C)[n+]([R])c1ccccc21</smiles><smiles>[R]n1cc(C(=O)C#CC)c2ccccc21</smiles>

3aa: $\mathrm{R}=\mathrm{Me} ; 85 \%$ 3ba: $\mathrm{R}=$ Allyl; $86 \%$ 3ca: $\mathrm{R}=\mathrm{Bn} ; 84 \%$ 3da: $\mathrm{R}=\mathrm{Ph} ; 86 \%$ 3ea: $\mathrm{R}=p$-Tolyl; $77 \%$ 3fa: $\mathrm{R}=\mathrm{Ts} ;$ n.r.<smiles>[R1]c1ccccc1-c1cn(C)c2ccccc12</smiles>

3ga: $\mathrm{R}=4-\mathrm{Me} ; 70 \%$ 3ha: $\mathrm{R}=5-\mathrm{Me} ; 85 \%$ 3ia: $\mathrm{R}=6-\mathrm{Me} ; 65 \%$ 3ja: $\mathrm{R}=7-\mathrm{Me} ; 81 \%$ 3ka: $\mathrm{R}=5-\mathrm{OMe} ; 49 \%$ 3la: $\mathrm{R}=6-\mathrm{OMe} ; 38 \%$<smiles>Cn1cc(C(=O)C#CI)c2cc[R1]cc21</smiles>

3ma: $\mathrm{R}=5-\mathrm{COOMe} ; 86 \%$

3na: $\mathrm{R}=5-\mathrm{Br} ; 80 \%$

3oa: $\mathrm{R}=6-\mathrm{Br} ; 88 \%$

3pa: $\mathrm{R}=6-\mathrm{Cl} ; 90 \%$

3qa: $\mathrm{R}=6-\mathrm{F} ; 88 \%$<smiles>O=C(C#Cc1cn([AlH2])c2cc[R][14cH]c12)c1ccccc1</smiles>

3ra: $\mathrm{R}=5$-COOMe; $65 \%$ 3sa: $\mathrm{R}=5-\mathrm{Br} ; 78 \%$ 3ta: $\mathrm{R}=5-\mathrm{Me} ; 62 \%$

3ua: $\mathrm{R}=6-\mathrm{Me} ; 70 \%$

3va: $\mathrm{R}=7-\mathrm{Me} ; 87 \%$

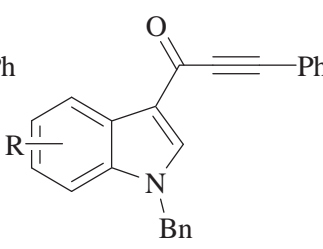

3wa: $\mathrm{R}=5-\mathrm{Me} ; 90 \%$ 3xa: $\mathrm{R}=6-\mathrm{Me} ; 88 \%$ 3ya: $\mathrm{R}=5-\mathrm{Br}$; n.r

Scheme 2. Direct Sonogashira carbonylation reactions of different indoles with phenylacetylene. Reaction conditions: $\mathbf{1}(0.5 \mathrm{mmol}), \mathbf{2 a}(1.0 \mathrm{mmol}), \mathrm{I}_{2}$ (1.2 mmol), $\mathrm{K}_{2} \mathrm{CO}_{3}(1.5 \mathrm{mmol})$, CuI (3 mol\%) and Pd(OAc) $2(5 \mathrm{~mol} \%)$ in DMF $(3.0 \mathrm{ml})$ under $\mathrm{CO}(0.2 \mathrm{MPa})$ at $90{ }^{\circ} \mathrm{C}$ for $24 \mathrm{~h}$. The isolated yield has also been provided. 


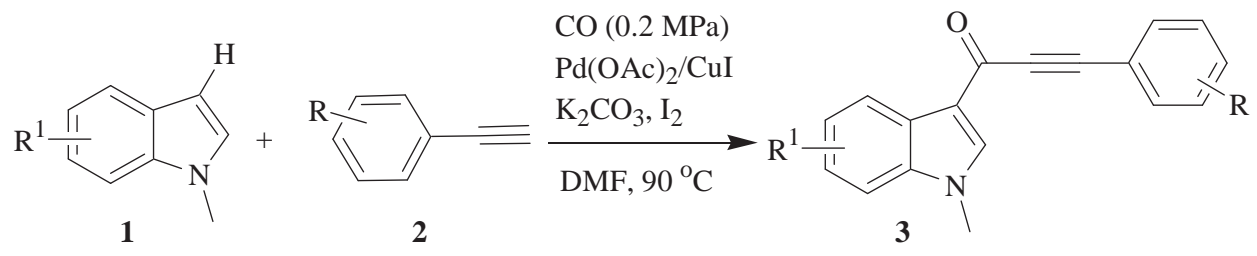<smiles>[R]c1ccc(C#CC(=O)c2cn(C)c3ccccc23)cc1</smiles>

3aa: $\mathrm{R}=\mathrm{H} ; 85 \%$
3ab: $\mathrm{R}=\mathrm{Me} ; 78 \%$
3ac: $\mathrm{R}=\mathrm{Et} ; 83 \%$
3ad: $\mathrm{R}=t$-Bu; $75 \%$
3ae: $\mathrm{R}=\mathrm{F} ; 89 \%$
3af: $\mathrm{R}=\mathrm{OMe} ; 92 \%$

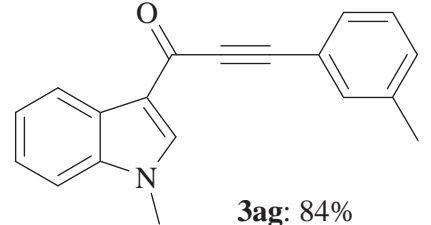

3ag: $84 \%$<smiles>[R]c1ccc(C#CC(=O)c2cn(C)c3ccc(Br)cc23)cc1</smiles>

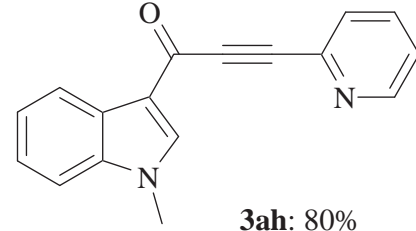

3ah: $80 \%$

3hb: $\mathrm{R}=\mathrm{Me} ; 80 \%$

3hd: $\mathrm{R}=t-\mathrm{Bu} ; 85 \%$ 3he: $\mathrm{R}=\mathrm{F} ; 86 \%$

$\mathrm{R}=\mathrm{Me} ; 90 \%$

3sd: $\mathrm{R}=t$-Bu; $92 \%$

3sf: $\mathrm{R}=\mathrm{OMe} ; 94 \%$

3se: $\mathrm{R}=\mathrm{F} ; 63 \%$

Scheme 3. Direct Sonogashira carbonylation reactions of $N$-methyl indole with different aryl alkynes. Reaction conditions: 1 (0.5 mmol), 2 (1.0 mmol) $\mathrm{I}_{2}(1.2 \mathrm{mmol}), \mathrm{K}_{2} \mathrm{CO}_{3}(1.5 \mathrm{mmol})$, CuI $(3 \mathrm{~mol} \%)$ and $\mathrm{Pd}(\mathrm{OAc})_{2}(5 \mathrm{~mol} \%)$ in DMF $(3.0 \mathrm{ml})$ under $\mathrm{CO}(0.2 \mathrm{MPa})$ at $90{ }^{\circ} \mathrm{C}$ for $24 \mathrm{~h}$. The isolated yields have also been provided.

the desired products in yields of 75\%-92\% (3aa-3af), indicating that the electronic properties of the substituents at the $p$-position had a limited effect on the outcome of the reaction. Interestingly, 2-ethynylpyridine was well tolerated under the reaction conditions to give the desired product (3ah) in good yield with none of the Pd-pyridine coordination species being observed. 1,5-Dimethylindole also reacted well with the phenylacetylene derivatives, and the structure of a representative product was clearly confirmed by X-ray single crystal diffraction analysis (Scheme 4. 3he, CCDC number: 885832). An electron-effect was only observed when the Sonogashira carbonylative coupling reaction was carried out using 5-bromo-1-methylindole and a variety of different substituted phenylacetylenes (3sb-3se). In this series, the presence of an electron-donating group (e.g., methyl, $t$-butyl or methoxy group) at the $p$-position (3sb-3sf) of $\mathbf{2}$ effectively facilitated the carbonylation reaction, whereas the presence of an electron-withdrawing group (e.g., F) had an adverse impact on the reaction.

\subsection{Triazole synthesis}

The preparation and properties of 1,2,3-triazole derivatives have been extensively studied because they can act as versatile building blocks in organic chemistry as well as functional mate-

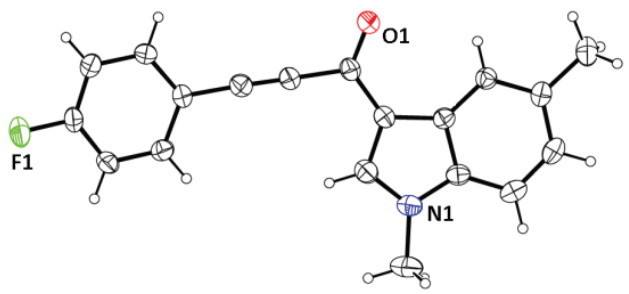

Scheme 4. X-ray crystal structure of 3 he. rial in a variety of other areas of scientific interest. In 2010, $\mathrm{Li}$ et al. [28] developed an efficient one-pot three-component method for the synthesis of 2,4,5-substituted triazoles that did not require the presence of a catalyst [28]. Inspired by this work, we envisaged that indole-3-alkynone (3) could be used in a one-pot transformation to give the corresponding triazole analogue (4) under similar reaction conditions. As shown in Scheme 5, the desired product $\mathbf{4 a}$ was obtained in $90 \%$ yield following the reaction of 3aa with benzyl bromide and sodium azide in DMSO for $4 \mathrm{~h}$ at room temperature. Based on the success of this reaction, we proceeded to investigate the substrate scope of the reaction. When $\mathbf{3}$ had a methyl group at the $\mathrm{R}^{1}$ position, the nature of the substituent at the $\mathrm{R}^{2}$ position did not affect the reaction with products $\mathbf{4 b}$ and $\mathbf{4 c}$ being formed successfully with similar yields (87\% and $86 \%)$. When halides

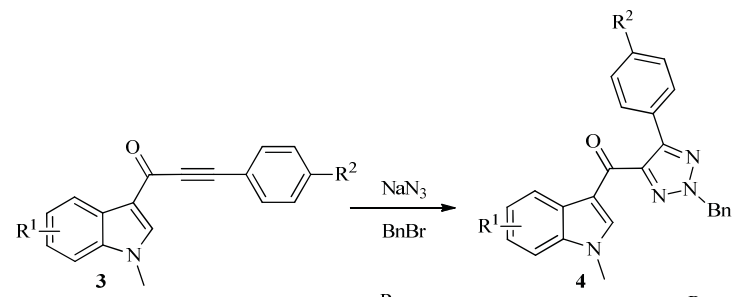<smiles>[R]c1ccc(Cn2nc(C(=O)c3cn(C)c4ccc(Br)cc34)c(-c3ccc([R])c(-c4nn(Cc5ccccc5)nc4C(=O)c4cn(C)c5ccc(C)cc45)c3)n2)cc1</smiles>

Scheme 5. One-pot synthesis of triazole analogues. Reaction conditions $3(0.25 \mathrm{mmol}), \mathrm{NaN}_{3}(0.5 \mathrm{mmol})$ and benzyl bromide $(0.5 \mathrm{mmol})$ in DMSO $(3.0 \mathrm{ml})$ at $25{ }^{\circ} \mathrm{C}$ for $4 \mathrm{~h}$. The isolated yields have also been pro- 
were present at the $\mathrm{R}^{1}$ and $\mathrm{R}^{2}$ positions, the product $\mathbf{4 d}$ was formed in a lower yield (75\%). In contrast, a higher yield was observed when $\mathrm{R}^{1}$ was the bromide and $\mathrm{R}^{2}$ was a methoxy group (4e).

The structures and purities of all of the products were confirmed by NMR and HRMS analyses. The data for two representative examples have been listed below.

3he. ${ }^{1} \mathrm{H}$ NMR (400 MHz, $\left.\mathrm{CDCl}_{3}\right) \delta 8.34(\mathrm{~m}, 1 \mathrm{H}), 7.86(\mathrm{~s}, 1 \mathrm{H})$, 7.59-7.53 (m, 2H), $7.26(\mathrm{~m}, 3 \mathrm{H}), 7.02(\mathrm{~m}, 2 \mathrm{H}), 3.80(\mathrm{~s}, 3 \mathrm{H}) .{ }^{13} \mathrm{C}$ NMR (101 MHz, $\left.\mathrm{CDCl}_{3}\right) \delta 171.0(\mathrm{C}=0), 164.8,162.3,138.9$, 137.8, 134.9, 134.8, 125.8, 123.9, 123.1, 122.5, 118.4, 117.0, 116.9, 116.2, 116.0, 109.9, 87.8, 86.6, 33.8. HRMS (ESI) Calcd for $\mathrm{C}_{18} \mathrm{H}_{13} \mathrm{FNO}:[\mathrm{M}+\mathrm{H}]^{+}, 278.0976$; Found: 278.0966.

4a. ${ }^{1} \mathrm{H}$ NMR (400 MHz, $\left.\mathrm{CDCl}_{3}\right) \delta 8.43(\mathrm{~m}, 1 \mathrm{H}), 7.88(\mathrm{~s}, 1 \mathrm{H})$, 7.33-7.22 (m, 13H), 5.59 (s, 2H), 3.68 (s, 3H). ${ }^{13} \mathrm{C}$ NMR (101 $\left.\mathrm{MHz}, \mathrm{CDCl}_{3}\right) \delta 181.0,148.7,144.0,139.4,137.4,134.9,130.2$, $128.9,128.8,128.8,128.6,128.3,128.2,127.3,123.6,122.9$, 122.9, 115.8, 109.6, 59.1, 33.6. HRMS (ESI) Calcd for $\mathrm{C}_{25} \mathrm{H}_{20} \mathrm{~N}_{4} \mathrm{NaO}:[\mathrm{M}+\mathrm{Na}]^{+}, 415.1529$; Found: 415.1532.

\subsection{Mechanistic consideration}

The active species in a Pd-catalyzed oxidative carbonylation of a $\mathrm{C}-\mathrm{H}$ bond is $\mathrm{Pd}(\mathrm{II})$, which is converted to the inactive $\mathrm{Pd}(0)$ species under the $\mathrm{CO}$ atmosphere, leading to a reduction in the rate of the reaction. To overcome this limitation, an alternative strategy was proposed where the aryl $\mathrm{C}-\mathrm{H}$ bond would be initially oxidized instead of the catalyst to regioselectively afford a functionalized intermediate that could participate in the $\mathrm{Pd}(0)$-catalyzed carbonylation to yield the desired carbonyl compound. In practice, iodine was used as the oxidant in accordance with related studies. The mechanism of the current carbonylation coupling was envisaged to proceed as depicted below (Scheme 6). The indole, $N$-methylindole (1a) in this example, is originally oxidized to 3-iodo-1-methylindole (A), which could be detected by GC/MS analysis. The reactive $\mathrm{Pd}(0)$ species generated from the $\mathrm{CO}$ reduction of $\mathrm{Pd}(\mathrm{II})$ would

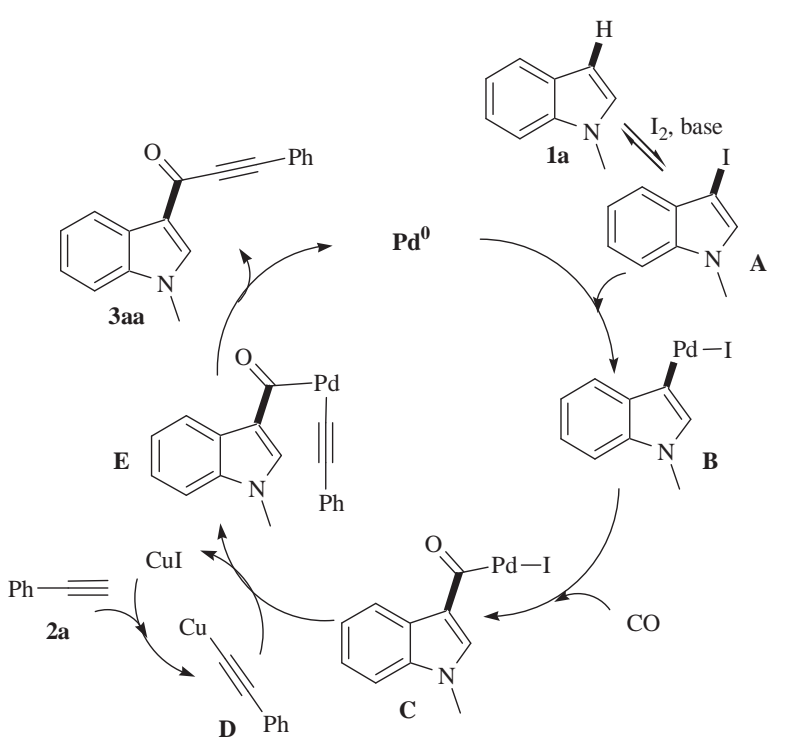

Scheme 6. Proposed reaction mechanism. then initiate the oxidative addition to afford intermediate $\mathbf{B}$. Subsequent insertion of CO would yield the Pd(II) acyl intermediate $\mathbf{C}$ that would undergo transmetalation with $\mathbf{D}$ to generate E. Finally, the target product 3aa would be released following the reductive elimination, and $\operatorname{Pd}(0)$ would be simultaneously regenerated to start a new catalytic cycle.

\section{Conclusions}

In conclusion, we have successfully developed an efficient strategy for the synthesis of indole-3-alkynones via the $\mathrm{Pd}(\mathrm{OAc})_{2} / \mathrm{CuI}-$ catalyzed direct Sonogashira carbonylation of a variety of different indoles and aryl alkynes. This methodology showed a wide substrate scope for indoles and alkynes with a high level of regioselectivity. Furthermore, the alkynone products could be readily transformed to 1,2,3-triazole derivatives in high yields. Further exploration of the reaction mechanism and potential synthetic applications of the present method are under investigation in our laboratory.

\section{References}

[1] Karpov A S, Merkul E, Rominger F, Müller T J J. Angew Chem, Int Ed, 2005, 44: 6951

[2] Karpov A S, Müller T J J. Org Lett, 2003, 5: 3451

[3] Wu X F, Neumann H, Beller M. Chem Soc Rev, 2011, 40: 4986

[4] Liu J M, Zhang R Z, Wang S F, Sun W, Xia C G. Org Lett, 2009, 11: 1321

[5] Wu X F, Neumann H, Beller M. Chem Eur J, 2010, 16: 12104

[6] Wu X F, Sundararaju B, Neumann H, Dixneuf P H, Beller M. Chem Eur J, 2011, 17: 106

[7] Wu X F, Neumann H, Beller M. Angew Chem, Int Ed, 2011, 50: 11142

[8] Giri R, Yu J Q.J Am Chem Soc, 2008, 130: 14082

[9] Guan Z H, Ren Z H, Spinella S M, Yu S C, Liang Y M, Zhang X M. J Am Chem Soc, 2009, 131: 729

[10] Haffemayer B, Gulias M, Gaunt M J. Chem Sci, 2011, 2: 312

[11] Li F W, Xia C G. J Catal, 2004, 227: 542

[12] Li F W, Peng X G, Xia Ch G, Hu B. Chin J Chem (李福伟, 彭新高, 夏春 谷, 胡斌. 中国化学), 2005, 23: 643

[13] Peng X G, Li F W, Xia C G. Synlett, 2006: 1161

[14] Li F W, Xia C G. Tetrahedron Lett, 2007, 48: 4845

[15] Liu J M, Peng X G, Liu J H, Zheng S Z, Sun W, Xia C G. Tetrahedron Lett, 2007, 48: 929

[16] Zheng S Z, Xia C G. Tetrahedron Lett, 2007, 48: 5883

[17] Zheng S Z, Peng X G, Liu J M, Sun W, Xia C G. Helv Chim Acta, 2007, 90: 1471

[18] Zheng Sh Zh, Peng X G, Liu J M, Sun W, Xia Ch G. Chin J Chem (郑书 展, 彭新高, 刘建明, 孙伟, 夏春谷. 中国化学), 2007, 25: 1065

[19] Peng X G, Li F W, Hu X X, Xia Ch G, Sandoval C A. Chin J Catal (彭新 高, 李福伟, 胡霄雪, 夏春谷, Sandoval C A. 催化学报), 2008, 29: 638

[20] Shi L J, Ren Y Ch, Xia Ch G, Li F W. J Mol Catal (China) (石利军, 任业 超, 夏春谷, 李福伟. 分子催化), 2011, 25: 289

[21] Xue L Q Shi L J, Han Y, Xia C G, Huynh H V, Li F W. Dalton Trans, 2011, 40: 7632

[22] Lang R, Wu J L, Shi L J, Xia C G, Li F W. Chem Commun, 2011, 47: 12553

[23] Lang R, Shi L J, Li D F, Xia C G, Li F W. Org Lett, 2012, 14: 4130

[24] Xing Q, Shi L J, Lang R, Xia C G, Li F W. Chem Commun, 2012, 48: 


\section{Graphical Abstract}

Chin. J. Catal., 2013, 34: 185-192 doi: 10.1016/S1872-2067(11)60491-9

\section{Palladium-catalyzed synthesis of indole-3-alkynones via direct carbonylation of indoles}

LI Dengfeng, SHAN Shang, SHI Lijun, LANG Rui, XIA Chungu, LI Fuwei*

Lanzhou Institute of Chemical Physics, Chinese Academy of Sciences; Zhejiang University of Technology

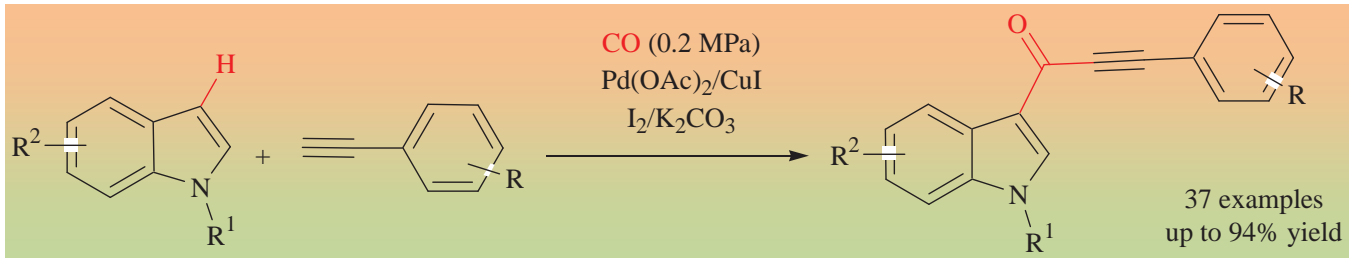

An efficient strategy has been developed for the synthesis of indole-3-alkynones involving sequential oxidative iodination and $\mathrm{Pd}(0)$-catalyzed carbonylation processes. The products could be further applied to the synthesis of triazole derivatives.

11023

[25] Naruse Y, Ito Y, Inagaki S. J Org Chem, 1991, 56: 2256

[26] Gagosz F, Zard S Z. Org Lett, 2002, 4: 4345
[27] Huang Y, Miao H, Zhang Q, Chen C, Xu J. Catal Lett, 2008, 122: 344

[28] Li J, Zhang Y, Wang D, Wang W, Gao T, Wang L, Li J, Huang G, Chen B. Synlett, 2010: 1617

\section{钯催化吲哚直接羰化合成吲哚-3-炔酮类化合物}

李登峰 ${ }^{\mathrm{a}, \mathrm{b}}$, 单 尚 ${ }^{\mathrm{b}}$, 石利军 ${ }^{\mathrm{a}}$, 郎 睿 ${ }^{\mathrm{a}}$, 夏春谷 ${ }^{\mathrm{a}}$, 李福伟 ${ }^{\mathrm{a},{ }^{*}}$

$\mathrm{a}$ 中国科学院兰州化学物理研究所羰基合成与选择氧化国家重点实验室, 甘肃兰州 730000

b 浙江工业大学化学工程与材料学院, 浙江杭州 310014

摘要: 以 $\mathrm{Pd}(\mathrm{OAc})_{2}$ 为主催化剂, 以 $\mathrm{Cu}$ 为助催化剂, 以碘为氧化剂, 高效地实现了吲哚与苯炔直接羰化合成吲哚-3-炔酮, 并优化了反 应条件. 结果表明,该催化剂体系对带有不同取代基的吲哚、端炔类化合物具有非常好的适用性,最高分离产率可达 $94 \%$. 生成的 吲哚-3-炔酮产物可进一步与叠氮化钠和澳苄一锅反应, 高产率地得到3-甲酰三唑基吲哚类化合物. 由于原料来源简单, 产率高, 且 两类产物都是重要的中间体,因此该方法具有一定的应用价值.

关键词: 羰基化; 一氧化碳; 钯; 吲哚-3-炔酮; 3-甲酰三唑基吲哚

收稿日期: 2012-11-06. 接受日期: 2012-11-20. 出版日期: 2013-01-20.

*通讯联系人. 电话: (0931)4968528; 传真: (0931)4968129; 电子信箱: fuweili@licp.cas.cn

基金来源：国家自然科学基金 (21002106 和21133011).

本文的英文电子版由Elsevier出版社在ScienceDirect上出版(http://www.sciencedirect.com/science/journal/18722067).

\section{1. 前言}

炔酮化合物是一类重要的有机中间体, 广泛应用于 多种具有生物活性的天然产物或杂环类化合物的合 成 ${ }^{[1]}$. 如图式1所示, 酰氯和端炔类化合物在Pd催化下的 偶联反应是制备炔酮的传统方法(path 1$)^{[2]}$. 由于酰氯化 学性质不稳定, 不易操作, 且某些特殊底物的酰氯中间体 (比如吲哚甲酰氯) 难以制备, 阻碍了该方法在催化合成 炔酮中的应用. 以简单易得的芳基卤化物、 $\mathrm{CO}$ 、端基炔 烃为原料, 在过渡金属催化下, 通过Sonogashira 羊炭化偶 联反应是合成炔酮的另一重要手段 (path 2) ${ }^{[3 \sim 6]}$. 常用的 芳香类底物主要是碘代或溴代芳烃. 2011年, $\mathrm{Wu}$ 等 ${ }^{[7]}$ 报
道了以苯胺为原料, 通过原位重氮化反应再进一步羰化 合成芳基炔酮的新方法, 拓展了该类反应的底物范围. 近年来, 通过活化芳环的 $\mathrm{C}-\mathrm{H}$ 键直接进行羰基化反应合 成相应的羧酸、酯、酰胺类化合物的研究得到了极大关 注 $^{[8 \sim 10]}$, 但是, 直接由未经任何功能化的(杂)芳环化合物 与端炔采用羰化偶联的方法制备炔酮目前尚未见报道.

吲哚类化合物广泛存在于自然界生物体和药物中; 其中含羰基的吲哚类衍生物大多具有生物活性. 近年来, 本课题组在原有工作 ${ }^{[11 ~ 19]}$ 的基础上又发展了一系列杂 环化合物的羰化反应 ${ }^{[20 ~ 24]}$. 本文报道以 $\mathrm{Pd}(\mathrm{OAc})_{2}$ 为主催 化剂, 以 $\mathrm{CuI}$ 为助催化剂, 以碘为氧化剂, 高效地实现吲哚 与苯炔直接羰化合成吲哚-3-炔酮 (图式1, path 3). 


\section{2. 实验部分}

\section{1. 吲哚与炔类化合物的代表性羰基化反应}

参照文献[25 27]合成 $N$-取代吲哚化合物. 吲哚和 苯乙炔类化合物为 AR, 天津Alfa试剂; 一氧化碳纯度 99.95\%; 硅胶(200 300目)及其它均为国产分析纯试剂.

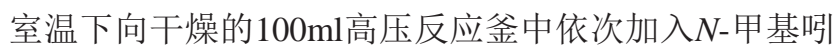
哚 $(\mathbf{1 a}, 0.5 \mathrm{mmol})$, 苯乙炔 $(\mathbf{2} \mathbf{a}, 1.0 \mathrm{mmol})$, 乙酸钯 $(5 \mathrm{~mol} \%)$, 单质碘 $(1.2 \mathrm{mmol})$, 碳酸钾 $(1.5 \mathrm{mmol})$, 碘化亚铜 $(3 \mathrm{~mol} \%)$, 溶剂 $N, N$-二甲基甲酰胺( DMF, 3.0ml). 随后在密闭状态 下用 $\mathrm{CO}$ 将反应釜置换三次, 再充入 $0.2 \mathrm{MPa}$ 的 $\mathrm{CO}$, 反应 器在 $90^{\circ} \mathrm{C}$ 下搅拌 $24 \mathrm{~h}$. 反应结束后, 硅胶柱分离得到产物 吲哚-3-炔酮(3aa)并计算相应的分离产率(洗脱液为石油 醚 $(\mathrm{PE})$ : 乙酸乙酯 $(\mathrm{EA})=5: 1)$, 产物用核磁 $($ AvanceTM $400 \mathrm{MHz}$ 超导核磁共振仪)与高分辨质谱(Bruker Daltonics micro TOF) 定性.

\section{3. 结果与讨论}

\section{1. 反应条件的篮选优化}

表1为不同反应条件下吲哚与炔类化合物的羰基化 反应结果. 首先以 $N$-甲基吲哚(1a) 和苯乙炔 $(\mathbf{2} \mathbf{a})$ 羰化合 成 $N$-甲基吲哚-3-苯乙炔酮(3aa) 为模板反应, 以乙酸钯 $\left(\mathrm{Pd}(\mathrm{OAc})_{2}\right)$ 为催化剂, 以 $1,1^{\prime}-$ 双 (二苯基膦)二茂铁 $(\mathrm{dppf}$, $5 \mathrm{~mol} \%$ ) 为配体, 以 $\mathrm{DMF}$ 为溶剂, 在 $\mathrm{K}_{2} \mathrm{CO}_{3}$ 和 $\mathrm{I}_{2}$ 的存在下, $110^{\circ} \mathrm{C}$ 反应 $24 \mathrm{~h}$. 反应结束后生成了目标产物 $3 \mathrm{aa}$, 但是产 率仅为 $49 \%$ (实验 1 ). 然而, 在不加膦配体的情况下, 催化 剂的活性反而更高, 3aa的产率增至 73\% (实验2). 众所周 知, 一价铜盐可与炔类化合物原位生成炔铜中间体. 我 们推测该中间体可能会与钯配合物发生转金属化作用, 从而进一步提高催化活性. 向体系中加入 $3 \mathrm{~mol} \%$ 的 $\mathrm{CuI}$ 以后, $3 \mathbf{a a}$ 的产率可提至 $82 \%$ (实验 3 ). 降低反应温度至 $90^{\circ} \mathrm{C}$, 可有效减少副产物联苯乙炔的生成, 使主产物的分 离收率达到 $85 \%$ (实验4). 不同碱条件下的实验结果表 明, 采用碱性较强的无机碱(如 $\mathrm{KOH}, \mathrm{CsCO}_{3}$ ) 和有机碱反 应效果均不理想, 而 $\mathrm{K}_{2} \mathrm{CO}_{3}$ 的使用明显促进了该反应的 进行 (实验 4 7). 还可以看出, 以 DMF 为溶剂反应效果最 好 (实验 4,8 10); 减少碱量不利于反应进行(实验4和 11 ), 且Pd催化剂和单质碘在反应中必不可少(实验12). 由此 确定了反应的最优化条件: $\mathrm{Pd}(\mathrm{OAc})_{2}$ 为主催化剂, $\mathrm{CuI}$ 为 助催化剂, $\mathrm{K}_{2} \mathrm{CO}_{3}$ 为碱, $\mathrm{I}_{2}$ 为氧化剂, $\mathrm{DMF}$ 为溶剂, $\mathrm{CO}$ 压力 $0.2 \mathrm{MPa}$, 反应温度 $90^{\circ} \mathrm{C}$, 反应时间 $24 \mathrm{~h}$. 此时目标产物的 产率为 $85 \%$ 。
3.2. 吲哚上的取代基团对吲哚与炔烃的羰基化合成炔 酮反应的影响

在上述优化的反应条件下, 考察了反应的底物适用 性, 结果见图式 2 . 首先考察了以苯乙炔为亲核试剂, 吲哚 上各种取代基对反应活性的影响. 由图可见, 当吲哚的 $\mathrm{N}$ 位带有甲基(Me)、烯丙基(Allyl)、苄基 $(\mathrm{Bn}) 、$ 苯基 $(\mathrm{Ph})$ 或甲苯基(Tolyl)等常见的取代基时, 反应的产率都在 $85 \%$ 左右 (3aa 3ea); 但用 $N$-对甲苯磺酰基 ( Ts)吲哚为原 料时, 没有检测到产物的生成(3fa), 说明㗱 $\mathrm{N}$ 位带强吸 电子基团,不利于该反应的进行.

随后, 考察了 $N$-甲基吲哚的苯环上各个位置带有取 代基时的反应(3ga 3qa), 发现当 $N$-甲基吲哚的4 7位上 带有给电子基(如甲基)时, 反应产物的产率中等(3ga 3ja), 且5-或7-甲基吲哚的产率(85\%,81\%)高于4-或6-甲 基吲哚的产率 $(70 \%, 65 \%)$. 同样, 5-甲氧基吲哚的活性略 高于6-甲氧基吲哚(3ka, 3la). 苯环上带有常见的吸电子 基团(如酯基等)的吲哚也适用于该反应体系(3ma 3qa), 且产率略高于带供电子基团的吲哚. 值得一提的是, 含 卤素 $(\mathrm{F}, \mathrm{Cl}, \mathrm{Br})$ 的吲哚在反应后可得到完好的保留, 并未 发生进一步的羰化反应(3oa 3qa). 这为此类产物提供

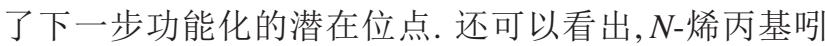
哚中含有酯基, 溴或甲基时, 反应均可达中等产率(3ra 3va); 而 $N$-茮基吲哚上含有给电子基, 产率可高达 $90 \%$ (3wa 3xa); 但为卤素基团时, 底物则完全不能反应(3ya).

\section{3. 苯乙炔上的取代基团对吲哚炔酮化反应的影响}

图式3为苯乙炔上取代基对反应的影响. 首先以 $N-$ 甲基吲哚(1a)为例来考察苯乙炔的对位取代基对反应的 影响(3aa 3af), 发现无论是给电子还是吸电子取代基都 可以得到令人满意的结果(产率 $75 \%$ 92\%), 说明苯乙炔 对位取代基的电子效应对反应的影响不大. 间-甲基苯 乙炔的活性也较高, 产率可达 $84 \%(3 \mathrm{ag})$; 出乎意料的是, 2-乙炔基吡啶在反应中并未出现与催化剂明显络合的 现象, 可以顺利地完成催化循环得到目标产物(3ah, 产率 $80 \%$ ). 当以 1,5 -二甲基吲哚为底物时, 对位取代的苯乙炔 表现出了相当高的反应活性 (3hb 3he). 我们还得到了 产物3he的单晶, 并通过X射线单晶衍射手段确定了该炔 酮化合物的结构(见图式 4, CCDC: 885832). 另外, 在 1-甲 基-5-溴吲哚与各种苯乙炔反应时, 存在明显的电子效应, 即对位带有给电子基的苯乙炔 $(3 \mathrm{sb}$ 3sf $)$ 活性大大高于 对位带有吸电子基(3se).

\section{4. 由吲哚-3-炔酮合成3-甲酰三唑基吲哚类化合物}

1,2,3-三唑特别是其多取代的衍生物具有重要生物 
活性, 可用于合成植物生长素、农药、抗生素、发光材 料等, 其合成与性质的研究受到广泛关注. 2010年, 陈宝 华课题组 ${ }^{[28]}$ 以芳基炔酮, 叠氮化钠, 芳基(或烷基)卤化物 为原料, 以 DMSO 为溶剂, 一锅法高区域选择性地合成 了 2,4,5-三取代的三唑化合物. 据此, 我们推测吲哚-3-炔 酮 (3) 可能也会发生类似的反应,生成相应的3-甲酰三唑 基吲哚(4), 如图式5所示. 我们先用产物 3aa为底物尝试 该简便的一锅合成反应, 在溶剂 DMSO中, 将 $\mathbf{3 a a}$ 与叠氮 化钠, 溴化茮在室温下搅拌, 发现目标产物 $\mathbf{4 a}$ 的产率可达 90\%. 进行底物扩展时发现, 当吲哚环上带有给电子基团 (如甲基)时(3hd 和 $3 \mathrm{he}$ ), 苯炔环对位上取代基的电子效 应并不明显, 3-甲酰-1,2,3-三唑基吲哚的产率都可达 $85 \%$ 以上 $(\mathbf{4 b}$ 和 $4 \mathrm{c})$; 而吲哚环和苯炔环上同时带有卤素 $(3 \mathrm{se})$ 时, 4 的产率明显降低 $(\mathbf{4 d}, 75 \%)$; 若吲哚-3-炔酮的炔烃苯 环上带供电子基团(3sf)时, 反应收率则可增至91\%(4e).

所有产物的结构和纯度均经过核磁和高分辨质谱 测定确证, 其代表性新化合物的数据如下.

3he. ${ }^{1} \mathrm{H}$ NMR $\left(400 \mathrm{MHz}, \mathrm{CDCl}_{3}\right) \delta 8.34(\mathrm{~m}, 1 \mathrm{H})$, $7.86(\mathrm{~s}, 1 \mathrm{H}), 7.59-7.53(\mathrm{~m}, 2 \mathrm{H}), 7.26(\mathrm{~m}, 3 \mathrm{H}), 7.02(\mathrm{~m}$, $2 \mathrm{H}), 3.80$ (s, 3H). ${ }^{13} \mathrm{C}$ NMR (101 MHz, $\left.\mathrm{CDCl}_{3}\right) \delta 171.0$ $(\mathrm{C}=\mathrm{O}), 164.8,162.3,138.9,137.8,134.9,134.8,125.8$, $123.9,123.1,122.5,118.4,117.0,116.9,116.2,116.0$, 109.9, 87.8, 86.6, 33.8. HRMS (ESI) calcd for $\mathrm{C}_{18} \mathrm{H}_{13} \mathrm{FNO}$ $278.0976\left([\mathrm{M}+\mathrm{H}]^{+}\right)$, found 278.0966.

4a. ${ }^{1} \mathrm{H}$ NMR (400 MHz, $\left.\mathrm{CDCl}_{3}\right) \delta 8.43(\mathrm{~m}, 1 \mathrm{H}), 7.88$ (s, 1H), 7.33-7.22 (m, 13H), 5.59 (s, 2H), $3.68(\mathrm{~s}, 3 \mathrm{H}) .{ }^{13} \mathrm{C}$ NMR $\left(101 \mathrm{MHz}, \mathrm{CDCl}_{3}\right) \delta 181.0,148.7,144.0,139.4$,
$137.4,134.9,130.2,128.9,128.8,128.8,128.6,128.3$, 128.2, 127.3, 123.6, 122.9, 122.9, 115.8, 109.6, 59.1, 33.6. HRMS (ESI) calcd for $\mathrm{C}_{25} \mathrm{H}_{20} \mathrm{~N}_{4} \mathrm{NaO} 415.1529\left([\mathrm{M}+\mathrm{Na}]^{+}\right)$, found 415.1532 .

\section{5. 反应机理}

在近期报道的 $\mathrm{C}-\mathrm{H}$ 键直接氧化羰化中, 高价态的催 化剂通常被视为引发催化循环的活性物种, 还原消除后 得到的低价态的金属中间体再被氧化剂转化为高价活 性物种, 开始下一轮循环. 但在 $\mathrm{CO}$ 气氛下, $\mathrm{Pd}(\mathrm{II})$ 易被还 原为 $\operatorname{Pd}(0)$, 使得引发循环的活性物种减少, 从而降低催 化活性. 我们采用氧化底物的策略, 可以得到相应官能 团化的反应物中间体, 再由 $\operatorname{Pd}(0)$ 引发催化过程, 最后还 原消除得到产物和 $\operatorname{Pd}(0)$. 根据已有的文献报道, 我们选 择碘来氧化底物. 吲哚的直接炔酮化反应机理可推测如 下(图式6): 吲哚在碱性条件下与碘生成3-碘吲哚 (A), 该 中间体可由气相色谱-质谱仪鉴定. $\operatorname{Pd}(0)$ 对3-碘吲哚的 $\mathrm{C}-\mathrm{I}$ 键氧化加成后, 发生 $\mathrm{CO}$ 的插入生成中间体 $\mathrm{C}, \mathrm{C}$ 与苯 乙炔的铜配合物(D) 可发生转金属作用生成中间体 $\mathbf{E}$, 再 发生还原消除得到目标产物 (3aa).

\section{4. 结论}

以碘为氧化剂, $\mathrm{Pd} / \mathrm{Cu}$ 双金属催化剂体系能够高效 地催化吲哚与芳基端炔的直接羰化合成吲哚-3-炔酮类 化合物, 该反应体系具有原料来源简单、活性高、底物 适用性广的优点, 且生成的吲哚-3-炔酮产物可再一步高 产率地转化为 3-甲酰三唑基吲哚类杂环化合物, 具有较 重要的合成应用价值. 